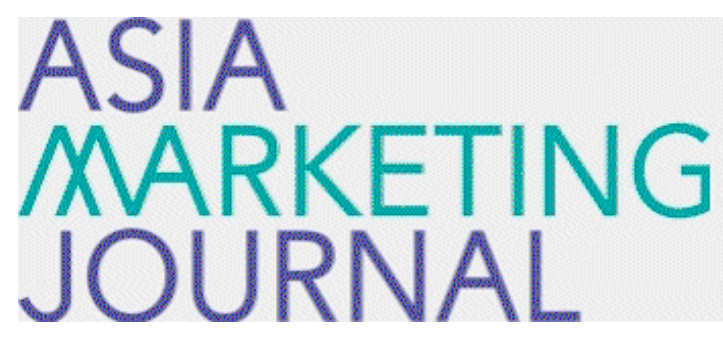

ASIA MARKETING JOURNAL

Volume 11 | Issue 2

Article 3

7-30-2009

\title{
The Roles of Market-Based Learning and Customer Orientation in Shaping Effective Selling Behavior and Efforts
}

Jeong Eun Park

Seong Jin Kim

Sung Ho Lee

Follow this and additional works at: https://amj.kma.re.kr/journal

Part of the Marketing Commons

\section{Recommended Citation}

Park, Jeong Eun; Kim, Seong Jin; and Lee, Sung Ho (2009) "The Roles of Market-Based Learning and Customer Orientation in Shaping Effective Selling Behavior and Efforts," Asia Marketing Journal: Vol. 11 : Iss. 2 , Article 3.

Available at: https://doi.org/10.53728/2765-6500.1235

This Article is brought to you for free and open access by Asia Marketing Journal. It has been accepted for inclusion in Asia Marketing Journal by an authorized editor of Asia Marketing Journal. 


\section{The Roles of Market-Based Learning and Customer Orientation in Shaping Effective Selling Behavior and Efforts*}

Park, Jeong Eun**

Kim, Seongjin***

Lee, Sungho****

Although previous studies have made significant progress in adaptive selling behavior (ASB), few studies have considered salesperson's customer orientation (CO) and learning behavior as determinants of effective sales management (ASB and relationship-making efforts), despite the discussion of important roles of these constructs. The authors test not only the relationships of salesperson's CO and market-based learning behavior to ASB and relationship-making efforts, but also the effects of ASB on relationship-making efforts and performance. The results of the study, which is done with samples of salespeople from Korean companies, indicate that salesperson's CO and market-based learning behavior are identified as significant determinants of ASB. Moreover, both salesperson's ASB and relationship-making efforts have significant effects on sales performance. On the other hand, as per salesperson's relationship-making efforts, salesperson's CO has a positive effect, but salesperson's market-based learning behavior and ASB do not influence his or her relationship-making efforts, which suggest a provocative possibility of conceptualization regarding the relationship between ASB and relationship management efforts.

Key words: Adaptive Selling Behavior, Market-based Learning, Customer Orientation, Relationship Marketing

This research is supported by the first author's research fund from Ewha Womans University(2007-1021-1-1).

** Assistant Professor of Marketing, College of Business Administration, Ewha Womans University(jepark@ewha.ac.kr), Corresponding and First Author

*** Doctoral Candidate, Business School Korea University(socialre@korea.ac.kr)

**** Professor of Marketing, College of Business \& Economics, University of Seoul(shlee@uos.ac.kr) 


\section{Introduction}

In his seminary paper, Weitz (1978) proposed effective selling (e.g. adaptive selling behavior, hereafter ASB) concept for understanding the characteristics of effective salespersons. Following this seminal research, a series of various studies have found various determinants of ASB: psychological variables (e.g., Spiro and Weitz 1990), organizational characteristics (e.g., Vink and Verbeke 1993), learning, goal and performance orientation (e.g., Park and Holloway 2003), cognitive process of adaptiveness (e.g., Porter and Inks 2000), and demographic variables (e.g., Robinson et al. 2002; Siguaw and Honeycutt 1995).

In addition, relationship efforts are another important variable in the contexts of strategy and sales (Park and Deitz 2004). Both academics and practitioners have paid an increasing attention to relationship management (Anderson 1996; Slater and Olson 2000). According to Slater and Olson (2000), a relational selling strategy is based on an exchange of critical information between a salesperson and a customer. In other words, the effects of effective selling behaviors and relationship efforts on performance have been examined in previous studies (Franke and Park 2006; Giacobbe et al. 2006). While our research will re-examine these relationships in the context of Korea, we propose the roles of new determinants in influencing $\mathrm{ASB}$ and relationship efforts.
Among the various determinants, some studies highlighted learning orientation, suggesting that learning orientation, as the motivation to improve selling skills, increases salespeople's willingness to modify their sales strategies (Ames and Archer 1988; Dweck and Leggett 1988). Also, Sujan, Weitz, and Kuma (1994) prove that learning orientation is related positively to ASB. Consistently, VandeWall, Cron, and Slocum (2001) suggest that learning orientation is more important in the development of effective selling behavior than performance orientation. By using Korean sample, Park and Holloway (2003) also reproved that learning orientation has a positive impact on ASB. Indeed, those studies have considered learning orientation as a motivation or a willingness of learning, not as a behavior. Though salespersons have a willingness of learning, it may not connect to an actual learning behavior. Sinkula (1994) insists that learning should take place through market information processing systems as the mechanism. In order to get over this limitation, we use learning behavior concept, i.e., market-based learning (hereafter MBL) instead of learning orientation, because MBL may be more appropriate for explaining effective salesperson behavior than orientation. Moreover, MBL is expected to influence salesperson to create and use customer information, facilitating salesperson's relationship efforts to make sales grow. Therefore, to examine the effects of MBL, as learning behavior, on $\mathrm{ASB}$ and relationship efforts warrant 
research efforts.

As additional important determinant of ASB and relationship efforts, we can think of one of Number 1 criteria as salesperson's competence, i.e., customer orientation (hereafter $\mathrm{CO}$ ). CO, described as a philosophy and behavior directed toward determining and understanding the needs of the target customer and adapting the selling organization's response (Williams 1998), concerns solving customers' problems, gathering information, and adapting to individual customers' needs (Bodkin 1989). Despite conceptually plausible relationship of $\mathrm{CO}$ to $\mathrm{ASB}$ and relationship efforts (e.g., Franke and Park 2006; Spiro and Weitz 1990), it is surprising that few studies investigate these relationships. Thus, we aim to examine these relationships.

Accordingly, the purposes of this research are: to review the existing studies of effective selling (ASB) and relationship efforts; and to identify key determinants (MBL and CO) and outcome (performance) of ASB and relationship efforts. Next, we provide a brief review of prior research on ASB. Then, the second section presents our conceptual framework, highlighting key antecedents and outcomes of effective selling behaviors and relationship efforts. In particular, we focus on the effects of two primary antecedents (MBL and CO) on ASB and relationship efforts. In the third section, a research methodology is explained, and the empirical results are presented. Finally, the paper concludes with a discussion of managerial implications, limitations, and future research directions.

\section{Conceptualization}

As the level of competition has increasingly intensified, recent research has emphasized the need for salespersons to learn and adapt to their rapidly changing environments (Park and Deitz 2004). Weitz, Sujan, and Sujan (1986) first proposed the conceptual model of adaptability and the relationships among knowledge structures, motivation, and practice of adaptive selling. Spiro and Weitz (1990), then, developed and validated the ASB measure with 16 items: ADAPTS. While some studies have discussed limitations of ADAPTS scale and proposed their own concepts and measures, many studies have examined the relationships between ASB and its determinants and outcomes, checking the nomological validity of ASB (i.e. Giacobbe et al. 2006; Robinson et al. 2002).

\subsection{Determinants of Effective Selling Behavior}

To sell adaptively, salespersons should learn fast-changing customer needs by using customer information (Hunt and Morgan 1996). Porter and Inks (2000) examine the cognitive process of adaptiveness and find that salespersons use different knowledge structures for selling across 
different situations. They also argue that the development of ASB scale include a salesperson's knowledge structure in order to fully understand the relationship between a salesperson's knowledge structure and ASB. In other words, to successfully carry out ASB, salespersons should develop the capability of learning and systematically use information process about customers. Sujan et al. (1994) suggest that goal orientation, performance orientation, and especially learning orientation, as the motivation to improve skills, should be the primary antecedents of ASB. They confirm that learning orientation has a positive influence on salesperson's willingness to practice adaptive sales. Further, VandeWalle et al. (2001) find that learning orientation is more important than performance orientation in the development of effective sales. Consistent with previous research, Park and Holloway (2003) find that learning has a significant effect on a salesperson's level of ASB.

On the other hand, Fiol and Lyles (1985) insist that behavioral change is required for learning to occur. Sinkula, Baker, and Noordewier (1997) also prove that learning orientation is a determinant of market information processing behaviors. In the context of selling, salesperson's market information processing behaviors, presumed to be driven by learning orientation, are also expected to influence his or her selling behavior. In other words, salesperson's market-based learning behavior will directly influence selling behavior such that selling behavior occurs, incorporating learning about customers and their needs. Therefore, we propose the following hypothesis:

H1: Salesperson's market-based learning is positively related to adaptive selling behavior.

$\mathrm{CO}$ is also described as a philosophy and behavior directed toward determining and understanding the needs of the target customer and adapting the selling organization's response (Williams 1998). Bodkin (1989) finds that customer orientation concerns solving customers' problems, gathering information, and adapting to individual customers' needs. Spiro and Weitz (1990) argue that customer orientation is correlated positively with ASB. In the context of their meta-analysis study, Franke and Park (2006) prove that $\mathrm{CO}$ would have a positive effect on ASB. However, there have been few empirical studies in which examine the direct relationship between $\mathrm{CO}$ and ASB. Based on conceptual argument of previous studies, we propose the following hypothesis:

\section{H2: Salesperson's customer orientation is positively related to adaptive selling behavior.}

Farrell (2000) finds that the higher learning orientation, the higher market orientation. CO is the most fundamental element of market orientation (Noble, Sinha, and Moorman 2002), and $\mathrm{MBL}$ is a behavioral variable of learning 
orientation (Park 2004). According to Narver and Slater(1990), CO is a cultural variable, whereas MBL is a behavioral variable. Therefore, $\mathrm{CO}$ as corporate culture is ahead of MBL as Behavior. In the context of selling, $\mathrm{CO}$ is also essential for salesperson to conduct a learning behavior, which leads to proposing the following hypothesis.

\section{H3: Salesperson's customer orientation is positively} related to market-based learning.

\subsection{Determinants of Relationship Efforts}

Several researchers have conceptualized the advantages accruing from the effective management of buyer-seller relationships (Day and Wensley 1983; Webster 1994). The efficacy of relational strategies emphasizing customer retention is described by studies suggesting that the acquisition of new customers costs a lot more than keeping and working with existing customers (Park and Deitz 2004; Reichheld 1996). To increase customer retention rate, salespersons systematically and efficiently gather, interpret, share, and memorize information regarding customers by using MBL. Therefore, we hypothesize:

H 4: Salesperson's market-based learning is positively related to relationship efforts.

Customer perception of CO facilitates salesperson's efforts in building trust and relationship (Stock and Hoyer 2005; Williams and Attaway 1996). Saxe and Weitz (1982) propose that customer orientation has a positive association with relational variables like cooperation, trust, and lack of conflict. In other words, $\mathrm{CO}$ is a very important orientation for salespeople to build and maintain their relationship with customers. Thus, we propose the following hypothesis:

H5: Salesperson's customer orientation is positively related to relationship efforts.

The effect of ASB on relationship-making efforts has not been tested empirically, although Siguaw (1991) proposes a similar conceptualization that an empathetic relationship between the salesperson and the customer results from the process of adaptive selling. That is, salesperson's ASB, backed by his or her customer orientation, will allow salesperson to approach their customers with the intention of making their relationship long-term. Therefore, we propose the following hypothesis:

H6: Salesperson's adaptive selling behavior is positively related to relationship efforts.

\subsection{Outcomes of Effective Selling Behavior and Relationship Efforts}

A lot of studies conclude that ASB increases salesperson's performance (e.g., Franke and Park 2006; Giacobbe et al. 2006). In the meta 
analysis, Franke and Park (2006) conclude that ASB has a strong effect on both subjective and objective measures of performance. Therefore, in re-examining the relationship between salesperson ASB and sales performance in context of Korea, we propose the following replication hypothesis:

H7: Salesperson's adaptive selling behavior is positively related to salesperson performance.

Some researchers find significant effects of relational mediators (relationship efforts) on seller's objective outcomes and organizational performance (Doney and Cannon 1997; Palmatier et al. 2006: Siguaw, Simpson, and Baker 1998). But several other studies have failed to empirically support the relationships, which implies that the effect of relational mediators on performance may be context-dependent (i.e. Gruen, Summers, and Acito 2000). To clarify the association between relationship efforts and performance, we propose the following hypothesis.

H8: Salesperson's relationship efforts are positively related to salespersons' performance.

\section{Method}

\subsection{Data Collection}

Data collection consisted of a convenience sample of salespersons from Korean companies. In recruiting the organizations to participate in the research study, companies were selected from different industries. A questionnaire and a personal letter were mailed to 600 salespersons. The response rate was $57.1 \%, 343$ of the total 600 salespersons. Of these 343 respondents, 17 were excluded due to incomplete responses. Hence, our usable responses were 326 (54.3\%). The sample showed that male respondents $(79.9 \%)$ were more than the female respondents $(19.1 \%)$.

\subsection{Measures}

The measures chosen for this study were drawn from previous studies and adapted for the context of this study. The measures used 7-point Likert-type scales. The anchors were either "1: strongly disagree" to "7: strongly agree" or "1: very unsatisfied" to "7: very satisfied."

As per the measures of the determinants of $\mathrm{ASB}$ and relationship efforts, those for MBL were modified from the study of Park (2004) to fit the context of salesperson's selling. In his research, MBL is composited by information gathering (selection), information interpretation (knowledge making), information sharing (knowledge sharing), and organizational memory. Information gathering means obtaining and selecting information for making useful knowledge. We measured salesperson's information gathering by the perceived amount of information and information selection time, consisting of 8 items (coefficient alpha = 
0.921). Information interpretation is defined as the process by which distributed information is given one or more commonly understood interpretations. We measured salesperson's information interpretation by the perceived quality of information, using 7 items (coefficient alpha $=0.880$ ). Information sharing is the process by which information from different sources is shared and leads to new information or understanding. We measured salesperson's information sharing by the perceived speed and level of information sharing, using 3 items (coefficient alpha $=0.873$ ). We measured salesperson's evaluation of organizational memory by the perceived level of accessibility and availability, using 3 items (coefficient alpha = 0.779). Moreover, CO was measured, using a multi-dimensional scale of 9 items from the Saxe and Weitz's (1982) SOCO scale (coefficient alpha $=0.883$ ).

As per the measures of ASB and relationship efforts, ASB was measured with a 16-item scale, adapted from the original scale of Spiro and Weitz (1990) (coefficient alpha $=0.927$ ). Relationship efforts were comprised of two dimensions (coefficient alpha $=0.899$ ) : trustbuilding and commitment-building. The trustbuilding of sales person was measured by using 4 items from Morgan and Hunt (1994). It was modified to fit salesperson's selling context. The commitment-building scales came from Lassar, Mittal, and Sharma (1995) and Garbarion and Johnson (1999). 5 items was used to measure the commitment-building.
To measure performance, salespersons were asked to evaluate themselves on achieving quantity and quality objectives, relative to other salespersons working for their company. We selected 7 items from Sujan et al. (1994) (coefficient alpha $=0.910$ ).

\subsection{Measurement Validity}

Consistent with Anderson and Gerbing (1988), first-order constructs were evaluated based on the following criteria: uni-dimensionality, reliability, and convergent and discriminant validity. The first-order CFA results, coefficient alpha, and modification indices are presented in 〈Table 1〉.

A pairwise comparison of the constructs in the modification indices indicates that one item (perf1 indicator) from performance needs to be eliminated from the construct, due to crossloaded into other constructs. All the latent-trait correlations between constructs are significantly different from one, establishing discriminant validity. As indicated by the squared multiple coefficient values, all items have a significant loading on their corresponding construct and the lowest $t$-value was 6.9, demonstrating adequate convergent validity. Finally, coefficient alphas of all variables exceeded the cut-off score of 0.70 (Nunnally 1978).

$\langle$ Table 2〉 shows a second-order CFA results. We conceptualize MBL as a second-order construct. First, we tested the null hypothesis that the first-order factors converge to a single higher- 
〈Table 1〉 The Results of Confirmatory Factor Analysis and Coefficient Alphas

\begin{tabular}{|c|c|c|c|c|c|c|c|c|c|c|c|}
\hline Construct & \multicolumn{10}{|c|}{ ASB $(\mathrm{a}=0.927)$} \\
\hline Indicators & asb1 & asb2 & asb3 & asb4 & asb5 & asb6 & asb7 & asb8 & asb9 & asb10 & asb11 \\
\hline Estimates & 1.00 & 0.99 & 0.79 & 0.97 & 1.03 & 1.01 & 0.96 & 0.71 & 0.75 & 0.81 & 1.00 \\
\hline (T-value) & - & $(15.07)$ & $(9.3)$ & $(12.43)$ & $(12.53)$ & $(11.79)$ & $(12.38)$ & $(8.81)$ & $(9.34)$ & $(9.76)$ & $(12.68)$ \\
\hline SMC & 0.51 & 0.53 & 0.29 & 0.51 & 0.52 & 0.46 & 0.51 & 0.26 & 0.29 & 0.32 & 0.53 \\
\hline
\end{tabular}

\begin{tabular}{|c|c|c|c|c|c|c|c|c|c|c|c|}
\hline Constructs & \multicolumn{5}{|c|}{ ASB $(a=0.927)$} & \multicolumn{5}{c|}{ Performance $(a=0.910)$} \\
\hline Indicators & asb12 & asb13 & asb14 & asb15 & asb16 & perf2 & perf3 & perf4 & perf5 & perf6 & perf7 \\
\hline Estimates & 0.99 & 0.95 & 0.80 & 0.98 & 0.98 & 1.00 & 1.20 & 1.29 & 1.29 & 1.29 & 1.19 \\
\hline (T-value $)$ & $(12.64)$ & $(12.1)$ & $(9.84)$ & $(12.39)$ & $(12.61)$ & - & $(12.31)$ & $(12.74)$ & $(12.83)$ & $(12.53)$ & $(12.25)$ \\
\hline SMC & 0.53 & 0.49 & 0.32 & 0.51 & 0.53 & 0.43 & 0.63 & 0.68 & 0.69 & 0.65 & 0.62 \\
\hline
\end{tabular}

\begin{tabular}{|c|c|c|c|c|c|c|c|c|c|c|c|}
\hline Constructs & \multicolumn{10}{|c|}{$\mathrm{CO}(\mathrm{a}=0.883)$} & \multicolumn{3}{c|}{$\mathrm{RE}(\mathrm{a}=0.899)$} \\
\hline Indicators & $\mathrm{co} 1$ & $\mathrm{c} 02$ & $\mathrm{co} 3$ & $\mathrm{c} 04$ & $\mathrm{c} 05$ & $\mathrm{c} 6$ & $\mathrm{co} 7$ & $\mathrm{co8}$ & $\mathrm{c} 09$ & trust & commit \\
\hline Estimates & 1 & 1.06 & 1.02 & 1.05 & 0.55 & 0.57 & 0.61 & 0.71 & 1.01 & 0.90 & 0.89 \\
\hline$(\mathrm{T}$-value $)$ & - & $(15.5)$ & $(14.68)$ & $(14.83)$ & $(6.9)$ & $(7.3)$ & $(7.52)$ & $(8.83)$ & $(13.16)$ & $(20.25)$ & $(20.57)$ \\
\hline $\mathrm{SMC}$ & 0.58 & 0.68 & 0.62 & 0.63 & 0.15 & 0.17 & 0.18 & 0.25 & 0.51 & 0.81 & 0.83 \\
\hline
\end{tabular}

order construct to establish the existence of a single second-order factor for MBL. A pairwise comparison of the constructs in the modification indices indicates that three items (infit3, infit6, om3 indicators) from MBL need to be eliminated from the construct, due to cross-loaded into other constructs. As indicated by the squared multiple coefficient values, all items have a significant loading on their corresponding construct and the lowest $t$-value was 13.45 , demonstrating adequate convergent validity. A unitary secondorder factor analysis fits the data very well: $x^{2}$ $($ d.f. $=127)=258.224$, RMSEA $=.0565, \mathrm{CFI}$ $=0.991, \mathrm{NNFI}=0.983, \mathrm{RMR}=0.0534, \mathrm{GFI}$ $=0.919$, AGFI $=0.890$. There is an evidence of convergence of the variable indicators within their respective first-order factors (infg, infit, infs, and om) and convergence of the firstorder factors within the second-order construct. Coefficient alphas also exceeded the cut-off score of 0.70 (Nunnally 1978).

\section{Analysis and Results}

\subsection{Results of Hypotheses Tests}

The hypotheses were examined in the structural model using LISREL8.8. The standardized parameter estimates for the measurement relationships and structural paths of the model

\section{4 한국마케팅저널 제11권 제2호 2009년 7월}


〈Table 2〉 Market-Based Learning (MBL) Second-Order Measurement Model

\begin{tabular}{|c|c|c|c|c|c|c|c|c|c|c|c|}
\hline Constructs & \multicolumn{9}{|c|}{ Information Gathering $(a=0.921)$} & \multicolumn{2}{|c|}{ Information- } \\
\hline Indicators & infg1 & infg2 & infg3 & infg4 & infg5 & infg6 & \multicolumn{2}{|c|}{ infg7 } & infg8 & infit1 & infit2 \\
\hline Estimates & 1.00 & 0.96 & 0.92 & 0.90 & 0.99 & 0.94 & \multicolumn{2}{|c|}{1.03} & 1.09 & 1.00 & 0.99 \\
\hline (T-value) & - & (15.93) & (13.73) & (14.76) & (16.41) & $(15.79)$ & \multicolumn{2}{|c|}{$(16.63)$} & $(15.05)$ & - & (17.18) \\
\hline SMC & 0.66 & 0.60 & 0.48 & 0.54 & 0.63 & 0.59 & \multicolumn{2}{|c|}{0.64} & 0.70 & 0.58 & 0.58 \\
\hline Constructs & \multicolumn{4}{|c|}{ interpretation $(a=0.880)$} & \multicolumn{5}{|c|}{ Information Sharing $(a=0.873)$} & \multicolumn{2}{|c|}{$\begin{array}{c}\text { Organizational } \\
\text { Memory }(a=0.779)\end{array}$} \\
\hline Indicators & infit4 & \multicolumn{2}{|c|}{ infit5 } & infit7 & infs1 & \multicolumn{2}{|c|}{ infs2 } & \multicolumn{2}{|c|}{ infs3 } & om1 & om2 \\
\hline Estimates & 1.13 & \multicolumn{2}{|c|}{1.13} & 1.07 & 1.00 & \multicolumn{2}{|c|}{1.00} & \multicolumn{2}{|c|}{0.91} & 1.00 & 0.87 \\
\hline (T-value) & $(13.45)$ & \multicolumn{2}{|c|}{$(15.19)$} & $(13.58)$ & - & \multicolumn{2}{|c|}{$(19.84)$} & \multicolumn{2}{|c|}{$(16.64)$} & - & $(14.04)$ \\
\hline SMC & 0.62 & \multicolumn{2}{|c|}{0.66} & 0.54 & 0.78 & \multicolumn{2}{|c|}{0.73} & \multicolumn{2}{|c|}{0.59} & 0.75 & 0.54 \\
\hline
\end{tabular}

\begin{tabular}{|c|c|c|c|c|}
\hline Constructs & \multicolumn{4}{|c|}{ MBL $(\mathrm{a}=0.913)$} \\
\hline Indicators & Information Gathering & Information Interpretation & Information Sharing & Organizational Memory \\
\hline Estimates & 0.97 & 0.88 & 0.96 & 0.99 \\
\hline (T-value $)$ & $(16.13)$ & $(15.24)$ & $(16.48)$ & $(15.90)$ \\
\hline SMC & 0.88 & 0.95 & 0.78 & 0.78 \\
\hline
\end{tabular}

are presented in 〈Figure 1〉. Although $x^{2}\left(\chi^{2}\right.$ $=1232.014$ with 604 degrees of freedom) is significant $(p=0.00)$, other goodness of fit statistics are strongly favorable: RMSEA = 0.0566; $\mathrm{CFI}=0.985 ; \mathrm{NNFI}=0.983 ; \mathrm{GFI}=$ $0.830 ;$ AGFI $=0.802$.

All the hypotheses are statistically significant except for $\mathrm{H} 4$ and $\mathrm{H} 6$. $\mathrm{H} 1$ and $\mathrm{H} 2$ posit that MBL (H1) and CO (H2) have an influence on ASB, which are supported. H4 and H5 hypothesize that MBL (H4) and CO (H5) have a positive effect on relationship efforts. H5 is supported, while $\mathrm{H} 4$ is not. H3 posits a positive relationship between $\mathrm{CO}$ and MBL, which is supported. H6 and $\mathrm{H} 7$ predict that $\mathrm{ASB}$ has a significant influence on relationship efforts (H6) and performance (H7). The relationship between ASB and performance (H7) is supported, but H6 is not supported significantly. Finally, we predict H8 that relationship efforts have an effect on performance, which is supported.

\subsection{The Mediating Role of MBL in the Effect of $\mathrm{CO}$ on $\mathrm{ASB}$}

We tested whether the relationships between $\mathrm{CO}$ and $\mathrm{ASB}$ were mediated by MBL. We compared the chi-square values of the more general models with those of the more restrictive model. The test was conducted by a 


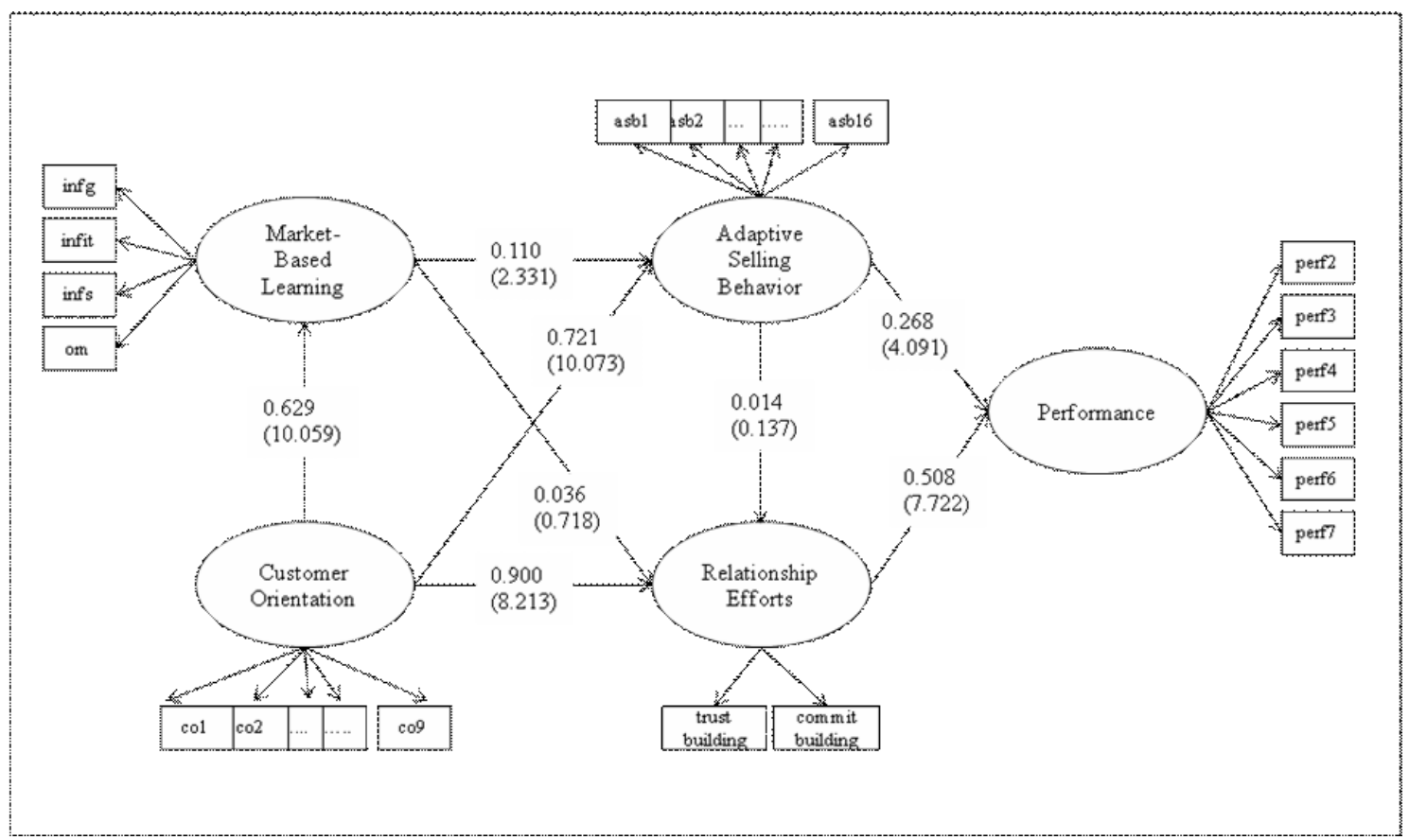

Chi-Square $=1232.014 ;$ d.f. $=604 ; \mathrm{P}-$ value $=0.000 ; \mathrm{RMSEA}=0.0566$

chi-square distribution with one degree of freedom (Bagozzi, Baumgartner, and Yi 1989). Our results show that chi-square value of the structural model doesn't differ significantly from the alternative model $\left(\Delta x^{2}=0\right)$. Therefore, the relationship between $\mathrm{CO}$ and $\mathrm{ASB}$ is not mediated by MBL.

\section{Discussion}

\subsection{Summary and Implications}

The primary objective of this study was to empirically examine the determinants and outcome of effective selling behaviors and relationship efforts. The results serve not only to add clarity to a number of previously unclear relationships, but also to extend our understanding of the overall processes of effective selling behavior and relationship efforts.

This research has some important implications for both researchers and practitioners. First, our research found that $\mathrm{MBL}$ plays an important role in effective selling. Several previous studies asserted that learning orientation has a direct effect on ASB. Whereas learning orientation is related with a willingness of information processing, MBL, as market information process behavior, 
helps salesperson to use the right information and the information in a right way for effective selling. Sinkula (1994) insists that learning orientation should be transformed into learning behavior. Likewise, in the context of selling behavior, salespersons, to increase sales, need to gather information about customers and competitors, produce and share knowledge, and maintain and use organizational memory of information and knowledge which is systematically collected and organized.

Second, CRM (Customer Relationship Management) becomes increasingly important, as customer retention is a more important factor for maintaining and increasing corporate performance than customer acquisition. For an effective CRM, it is important for salesperson as well as organization to gather, interpret, share, and memorize information and knowledge about customers and competitors. Thus, MBL, as a market information processing behavior, is an important variable for an effective CRM. However, the direct effect of MBL on relationship efforts is not supported in our study. We probe into the reason why this relationship may not hold. Learning orientation needs the requirements such as managerial support to be transformed into learning behavior. Likewise, learning behavior also requires a few conditions to be transferred to relationshipmaking efforts. Supporting benefits or rewards, different performance evaluation criteria, and/ or CRM technology may be such examples. Therefore, companies had better make efforts in promoting to transfer salesperson's MBL into relationship-making efforts.

Finally, we hypothesize that ASB has a significant effect on relationship-making efforts, but this hypothesis is rejected. This result may suggest a provocative possibility that ASB is an important determinant for the success of sales, not necessarily for relationship management efforts. That is, salespersons can act ASB to increase sales, even though they do not have an intention of relationship management. It cautiously suggests the possible conceptualization that ASB increases a short-term performance, whereas relationship making efforts increase a long-term performance. Therefore, it is very worthwhile to examine not only the conceptualization of the relationship between ASB and relationshipmaking efforts but also finding the roles of some moderators and/or mediators in the relationship between ASB and relationship efforts.

\subsection{Limitations and Suggestion for Future Research}

This research has several limitations. First, this research was conducted with a convenience sample of Korean companies. Future research should strive to confirm these findings with samples from different contexts and/or countries to increase the generalizability of our study findings. Second, the relationship between ASB and relationship quality needs to be more systematically explored, given that both ASB 
and relationship efforts have a significant effect on performance. Third, Podsakoff et al. (2003) show some sources of common method biases. Common method bias by this research is called "the consistency motif" or "the consistency effect" that is produced by common source or rater. To solve this problem, Podsakoff et al. (2003) recommend that behavioral scale is measured from more than two resources. We measured MBL and ASB, using behavioral measurements from common subjects, so our research could have common method biases. Therefore, it is needed to collect multi-source data for solving common method bias in future research. Finally, this research was conducted across several industries. Industrial characteristics could be used as moderators or mediators among MBL, ASB, CO, relationship efforts. In future research, these effects should be examined and confirmed.

〈논문 접수일: 2009. 02. 23〉

〈게재 확정일: 2009. 05. 23〉

\section{References}

Ames, Carol and Jennifer Archer (1988), "Achievement Goals in the Classroom: Students' Learning Strategies and Motivation Processes," Journal of Educational Psychology, 80 (3), 260-267.

Anderson, James C. and David W. Gerbing
(1988), "Structural Equation Modeling in Practice: A Review and Recommended Two-Step Approach," Psychological Bulletin, 103 (3), 411-423.

Anderson, R. E. (1996), "Personal Selling and Sales Management in the New Millennium," Journal of Personal Selling and Sales Management, 16 (Winter), 17-32.

Bagozzi, R. P., J. Baumgartner, and Yoojae Yi (1989), “An Investigation into the Role of Intentions as Mediators of the AttitudeBehavior Relationship," Journal of Economic Psychology, 10 (March), 35-61.

Bodkin, Charles D. (1989), “The Adaptive Behavior Construct and its Effect on Salesperson Performance," Doctoral Dissertation, Department of Marketing, Virginia Tech University.

Day, George and Robin Wensley (1983), "Marketing Theory with a Strategic Orientation," Journal of Marketing, 47 (Fall), 79-89.

Doney, Patricia and Joseph P. Cannon (1997), "An Examination of the Nature of Trust in Buyer-Seller Relationship," Journal of Marketing, 64 (April), 35-51.

Farrell, Mark A. (2000), "Developing a MarketOriented Learning Organisation," Australian Journal of Management, 25 (2), 201-222.

Fiol, C. Marlene and Marjorie A. Lyles (1985), "Organizational Learning," Academy of Management Review, 10 (4), 803-813. Franke, George R. and J.E. Park (2006), "Salesperson Adaptive Selling Behavior and 
Customer Orientation: A Meta-Analysis,"

Journal of Marketing Research, 43 (November), 93-702.

Garbarion, Ellen and Mark S. Johnson (1999), "The Different Roles of Satisfaction, Trust, and Commitment in Customer Relationships," Journal of marketing, 63 (April), 70-87.

Giacobbe, Ralph W., Donald W, Jackson Jr., Lawrence A. Crosby, and Claudia M. Bridges (2006), "A Contingency Approach to Adaptive Selling Behavior and Sales Performance: Selling Situations and Salesperson Characteristics," Journal of Personal Selling and Sales Management, 26 (Spring), 115-142.

Gruen, Tomas W., John O. Summers, and Frank Acito (2000), "Relationship Marketing Activities, Commitments, and Membership Behaviors in Professional Associations," Journal of Marketing, 64 (July), 34-49.

Hunt, Shelby D. and Robert M. Morgan (1996), "The Resource-Advantage Theory of Competition: Dynamics, Path Dependencies, and Evolutionary Dimensions," Journal of Marketing, 60 (October), 107-125.

Lassar, Walfried, Banwari Mittal, and Arun Sharma (1995), "Measuring Customer Based Brand Equity," Journal of Consumer Marketing, 12 (4), 11-19.

Morgan, Robert M. and Shelby D. Hunt (1994), "The Commitment-Trust Theory of Relationship Marketing," Journal of Marketing, 58 (July), 20-38.
Narver, J. C. and S. F. Slater(1990), "The Effect of a Market Orientation on Business Profitability," Journal of Marketing, 54 (October), 20-35.

Noble, Charles H., Rajiv K. Sinha, and Ajith Kumar (2002), "Market Orientation and Alternative Strategic Orientations: A Longitudinal Assessment of Performance Implications," Journal of Marketing, 66 (October), 25-39.

Nunnally, Jum C. (1978), Psychometric Theory, 2d ed. New York: McGraw-Hill.

Palmatier, Robert W., Rajiv P. Dant, Dhruv Grewal, and Kenneth R. Evans (2006), "Factors Influencing the Effectiveness of Relationship Marketing: A Meta-Analysis," Journal of Marketing, 70 (October), 136153.

Park, Jeong-Eun (2004), "The Impact of Marketing Outsourcing on Market-Based Learning Process," Unpublished Doctoral Dissertation Thesis, Department of Management and Marketing, University of Alabama. and Betsy B. Holloway (2003), "Adaptive Selling Behavior Revisited: An Empirical Examination of Learning Orientation, Sales Performance, and Job Satisfaction," Journal of Personal Selling and Sales Management, 23 (Summer), 237-249. and George D. Deitz (2006), "The Effect of Working Relationship Quality on Salesperson Performance and Job Satisfaction: Adaptive Selling Behavior in Korean Auto- 
mobile Sales Representatives," Journal of Business Research, 59 (February), 204-213. Podsakoff, Philip M., Scott B. Mackenzie, Jeong-Yeon Lee, and Nathan P. Podsakoff (2003), "Common Method Biases in Behavioral Research: A Critical Review of the Literature and Recommended Remedies," Journal of Applied Psychology, 88, 879-903. Porter, Stephen S. and Lawrence W. Inks (2000), "Cognitive Complexity and Salesperson Adaptability: An Exploratory Investigation," Journal of Personal Selling and Sales Management, 20 (Winter), 15-22.

Reichheld, F. F. (1996), "Learning from Customer Defections," Harvard Business Review, March-April, 56-69.

Robinson, Leroy, Jr., Greg W. Marshall, William C. Moncrief, and Felicia G. Lasek (2002), "Toward a Shortened Measure of Adaptive Selling," Journal of Personal Selling and Sales Management, 22 (Spring), 111-119. Saxe, Robert and Barton A. Weitz (1982), "The SOCO Scale: A Measure of the Customer Orientation of Salespeople," Journal of Marketing Research, 19 (August), 343-351.

Siguaw, Judy A. J. (1991), “The Relationships of Customer Orientation, Adaptive Selling and Selected Antecedents: A Causal Model," Dissertation, College of Administration and Business, Louisiana Tech University. and Earl D. Honeycutt, Jr. (1995), "An Examination of Gender Differences in Selling Behaviors and Job Attitudes," In- dustrial Marketing Management, 24, 5-52. , Penny M. Simpson, and Thomas L. Baker (1998), "Effects of Supplier Market Orientation on Distributor Market Orientation and the Channel Relationship: The Distributor Perspective," Journal of Marketing, 62 (July), 99-111.

Sinkula, James M. (1994), "Market Information Processing and Organizational Learning," Journal of Marketing, 58 (January), 35-45. - James M., William E. Baker, and Thomas Noordewier (1997), "A Framework for Market-Based Organizational Learning: Linking Values, Knowledge, and Behavior," Journal of the Academy of Marketing Science, 25 (4), 305-318.

Slater, Stanley and Eric M. Olson (2000), "Strategy Type and Performance: The Influence of Sales Force Management," Strategic Management Journal, 21 (8), 813-29.

Spiro, Rosann L. and Barton A. Weitz (1990), "Adaptive Selling: Conceptualization, Measurement, and Nomological Validity," Journal of Marketing Research, 27 (February), 61-69. Stock, Ruth Maria and Wayne D. Hoyer (2005), "An Attitude Behavior Model of Salespeople's Customer Orientation," Journal of the Academy of Marketing Science, 33 (Fall), 536-552.

Sujan, Harish, Barton A. Weitz, and Nirmalya Kumar (1994), "Learning Orientation, Working Smart, and Effective Selling," Journal of Marketing, 58 (July), 39-53. 
VandeWalle, Don, William L. Cron, and John W. Slocum, Jr. (2001), "The Role of Goal Orientation Following Performance Feedback," Journal of Applied Psychology, 86 (4), 629-640.

Vink, Jaap and William Verbeke (1993), "Adaptive Selling and Organizational Characteristics," Journal of Personal Selling and Sales Management, 13 (Winter), 15-25.

Webster, F. E. (1994), Market-Driven Management: Using the New Marketing Concept to Create a Customer-oriented Company, John Wiley and Sons, New York, NY.

Weitz, Barton A. (1978), "The Relationship Between Salesperson Performance and Understanding of Customer Decision Making," Journal of Marketing Research, 15 (November), 501-516.
Harish Sujan, and Mita Sujan (1986), "Knowledge, Motivation and Adaptive $\mathrm{Be}^{-}$ havior: A Framework for Improving Selling Effectiveness," Journal of Marketing, 50 (October), 174-191.

Williams, Michael R. (1998), "The Influence of Salespersons' Customer Orientation on BuyerSeller Relationship Development," Journal of Business and Industrial Marketing, 13 (Summer), 271-287. and Jill S. Attaway (1996), "Exploring Salespersons' Customer Orientation as a Mediator of Organizational Culture's Influence on Buyer-Seller Relationships," Journal of Personal Selling and Sales Management, 16 (Fall), 33-52. 